\title{
The Dilemma of Accountability and Good Governance for Improved Public Service Delivery in Nigeria
}

\author{
Adejuwon, Kehinde David
}

\begin{abstract}
The public sector in Nigeria is irrefutably beset with gross incompetence and ineffective management. Perplexing difficulties endure in the Nigerian public sector in spite of a number of reform programmes that have been designed to enhance efficient and effective service delivery for almost two decades. The fact that public service has failed dismally to achieve its laudable objectives is the reason for the vote of no confidence passed on its administrators by majority of the Nigerian populace. The article examines the dilemma of accountability and good governance in Nigeria and demonstrates that the critical point in achieving meaningful developments in the country intrinsically lay with improved service delivery in the public sector. The basic reason why the public service has become the scorn of the people is because for too long, both the government and public servants have paid lip service to the crucial issue of

article argues that improved service delivery will improve both the performance and the image of public service and re-awaken the citizens' interest and trust in them to do business with public servants. It suggests that in order to bring sanity back to the Nigerian Public Service, all unprofessional tendencies such as ethnicity bias and nepotism in appointments and promotions, lack of security of tenure of office, and appointment of non-career public servants into key positions in the public service must stop. Also, effective service delivery must be tailored to the circumstances of Nigeria. The study made use of secondary data obtained from various sources. It therefore concludes that without a reawakening of the culture of accountability and transparency lost over the years, the trusting relationship needed to forge between the government and the governed for the actualization of good governance will not materialize.
\end{abstract} effective and efficient service delivery. The

Keywords: Accountability, Public Service, Service Delivery, Corruption, Transparency, Good Governance, Nigeria 


\section{Introduction}

Public service delivery has been one of the key functions of the public sector. Traditionally in most parts of Africa until the recent past - mid 1980s and early 1990s the sector has been directly involved in delivering both core and none-core public services. The public service has been the main actor in the development process and in production and distribution of goods and services in most economies, especially those that embraced centrally planned economic policies. The commanding heights of these economies were directly owned and managed by the public sector (Honest, 2006:5). However, from the mid 1980s, following the winds of change in the form of many and far-reaching social, political and economic reforms, the role of the public sector in the development process have substantially changed.

Public service delivery is a fact of life for government. Citizens and businesses alike expect convenient access to government services and information through multiple channels; such as telecommunication, agriculture, transportation, education, etc. Many government agencies have traditionally functioned as separate business units, resulting in complex and disjointed communications. This leads to inefficiencies and service ineffectiveness, which serves to drive up costs. Meeting increasing service demands with fewer resources under constrained budgets is a major challenge for most governments (Mitel, 2007:19). As a result, a great deal of attention in development research and policy circles has recently focused on the efficacy of public expenditures in providing basic services to poor people, and on how actually making services work for the poor is constrained by weak incentives of public agents (World Development Report 2004:9; Fosu and Ryan, 2004:140).

Accountability is one of the cornerstones of good governance; however, it can be difficult for scholars and practitioners alike to navigate the myriad of different types of accountability. Recently, there has been a growing discussion within both the academic and development communities about the different accountability typologies. Given the absolute centrality of issues of public accountability to any discussion of contemporary governance, and the challenges facing government administration, it is obviously useful to explore the experience of various countries with different means and approaches to holding both public officials and civil servants accountable to the citizenry. Effective accountability mechanisms are powerful tools to improve service delivery by providing constructive assessments and motivating decision makers to avoid negative external critiques (Olarinmoye, 2011:34). Broadly speaking, the problem of accountability rests on incentives and selection. The first refers to the system of punishment and reward sequel to actions taken by agents. The second refers to the process of putting in place specific individuals to make decisions (Besley and Ghatak, 2007:136).

Improving public service delivery is one of the biggest challenges worldwide. Public services are key determinant of quality of life, not measured in per capita income. They are also an important plank of poverty reduction strategy. It is a particular challenge in Nigeria, given the low quality of service provisions and the pressing needs of the poor (Besley and Ghatak, 2007:152). In this context, accountability of public officials has been 
explored as a means of strengthening incentives of public providers for improved service delivery (Bardhan, 2002:21).

How accountable are public officials for the delivery of public services in Nigeria? This paper attempts to answer this question by providing evidence from Nigeria on the issue of accountability and good governance for the delivery of basic services to citizen.

The article is pigeonhole into five compartments. The first section is conceptualization of concepts; under this section the major concepts in the paper are explained. The second aspect explains the nexus between accountability and good governance, while the next section takes a cursory look at public accountability, good governance and effective service delivery from Nigerian perspective. The fourth section proffers remedial actions for improved service delivery in Nigeria, whilst the last section concludes the article.

\section{Conceptual Framework}

Arguably, conceptualizing words has often remained ambiguous. This is the intent of Babbie (1995:127) methodological research diction that "we specify what we use particularly terms for the purpose of facilitating their contextual operationalisation and comprehension. In order to ward off this ambiguity and to balance the concepts in this study, this article briefly discusses operational meanings attached to some of the key concepts used herein, viz; accountability, governance, good governance and service delivery.

\section{Accountability}

The notion of accountability is an amorphous concept that is difficult to define in precise terms. This according to Blind (2011:8) partly arises from its dualistic nature as a concept. According to him, accountability is abstract and value-ridden because it is associated with, inter alia, the notions of responsibility, integrity, democracy, fairness and justice. As noted by Roger and Mac-Williams (2001:46), accountability is said to have Roman origin denoting "To stand forth and be counted." Accountability means you have a hand in all things you have created, promoted, or allowed. It refers to the ability to furnish satisfactory analyses and explanation of one's actions in the process of discharging one's responsibilities at all levels, whether technical, administrative, political, financial, or otherwise (Ola \& Effiong, 1999:44).

In his own view, Okechukwu (2007:32) sees accountability as the execution of one's duties and conducts in public offices; it has been noted to constitute a powerful tool in the struggle for human right implementation. It makes it possible for people and organizations to identify important actors and hold them accountable for their actions. Accountability can also be seen as a relationship of power, where the less powerful 'principal' has the right to ask the more powerful 
'agent' to explain his/her actions, and has the capacity to impose penalties for poor performance. Peter Bird quoted in (Ola \& Effiong 1999:109) explains accountability thus:

Every steward is held accountable to the person or body which entrusted resources to him whether the latter is a superior steward or the ultimate owner. Accountability places two obligations upon a steward: he must render an account of his dealing with the stewardship resources, and then he must submit to an examination (usually known as an audit) of that account by or on behalf of the person or body to whom he is accountable. This means that he must not only allow the audit to take place, but he must provide the evidence from which the auditor can verify the account rendered. This double duty of stewards, including an audit, has a long and continuous history. The need for independent check or control (inspection or audit) lies deep in human history.

According to Stewart (in Hondeghorn, 1998:7), accountability rests both on giving an account and on being held to account. Ackerman (2005:18) stresses two variants of accountability: accountability as "honesty" and accountability as "performance." On an individual level, the first variant is associated with the rule-following bureaucrats who restrain from the nonprocedural, and the second variant, with the pro-active public decision-makers who are expected to perform efficiently and effectively. Ackerman indicates that the first "honesty" version is "process-oriented" and "negative" accountability because the public servants are evaluated through time, and based on the extent to which they abide by the standard operating principles. As for the second, "performance," understanding of accountability, the association is with "results-driven" and "positive" accountability insofar as accountability is seen as the ability to produce effective policy outcomes, which are evaluated at project endings.

Another scholar who has taken a step towards a continuous graded view of accountability is Joshi (2010:15). He focuses more specifically on accountability in the area of public service delivery which is the focus of this article. He favours the "short route" of accountability; i.e., the more visible and direct linkages between users (citizens) and providers (street-level bureaucrats) as opposed to the "long route," where elected politicians and public officials are accountable to the service-recipient citizens through the providers. In this more tightly circumscribed milieu, the continuous process of accountability is conceived to include the following stages: setting standards, getting information about actions, making judgments about appropriateness, and sanctioning unsatisfactory performance. According to Joshi (2010:22), there is high ambiguity in the literature about which stages are essential for a particular accountability initiative to be robust.

The concept of accountability involves two distinct stages; answerability and enforcement. Answerability refers to the obligation of the government, its agencies and public officials to provide information about their decisions and actions and to justify them to the public and those institutions of accountability tasked with providing oversight. Enforcement suggests that the public or the institution responsible for 
accountability can sanction the offending party or remedy the contravening behaviour. As such, different institutions of accountability might be responsible for either or both of these stages.

Arising from its conceptualization, accountability is considered a key determinant of the state of governance. Thus, strict observation of accountability in the management of public affairs promotes good governance while the lack of it is the major course of bad governance (Polidano \& Hulme, 1997:68). The system of accountability as we know it evolve in stages and closely tied to political watersheds. The evolution is ubiquitously similar, beginning with an enthusiastic pursuit for probity and integrity on the part of public administrators. The budgeting, accounting and auditing activities are geared towards guiding against abuse and misuse (Agbaje, 2006:83).

\section{The Concept of Good Governance}

The concept of good governance is not new. It is as old as human civilization. Etymologically and semantically, words like "governance" and "good governance" seem to belong to the same genus as very ancient terms like 'state' and 'government'. In fact, right from the recognition of the concept of government, either for the community or for the nation state, value premises have been developed as to how a government has to perform and how not to function. Thinkers and theorists have pondered upon the concept continuously.

The concept of governance is simple. In fact, Sahni (2004:39) noted that the concept of governance is not new and probably as old as human civilisation. It broadly means the process of decision-making and the process by which decisions are implemented or not implemented. According to him, the concept of governance relates to the quality of relationship between the government and the citizens who it serves and protects. Governance is emerging as an interactive process, aimed at balancing social forces and reconciling social interests and enabling the members of the society to organise themselves in realisation of goals.

Governance is seen as a set of values, policies and institutions through which the society manages the economic, political as well as social processes at different levels, on the basis of interaction among the government, civil society and private sector (Sahni, 2004:42). He defined governance further as one in which the concerned authority if any, exercise power, exerts influence and manages the country's social as well as economic resources leading to better development. In a more precise manner we can say that governance is the way those with power, use the power. This is in agreement with the World Bank's document on Africa that defined governance as the manner in which power is exercised in the management of a country's economic and social resources for development (World Bank, 1992:23). The Word Bank identifies three distinct aspects in the conceptualisation of 'governance' such as the form of political regime, the economic 
and social resources, and the capacity of governments to design, formulate and implement policies and in general, to discharge government functions.

Governance is the deliberate and conscious management of regime structures for enhancing public realm. Such conscious management according to Sahni (2004:45) could be done through different sets of tools including code of ethical behaviour, outcome-based performance assessment; result-based management; outcome measurement; balanced scorecard; social auditing; sharing best practices; information retrieval; competencies profiling; knowledge discovery; sharing and development; learning after action reviews, learning logs, decision diaries; intellectual capital measurement systems; integration-knowledge management and so forth. Governance for development ought to be accountable, participatory, responsive, effective, and efficient for promoting the rule of law, safeguarding the interests of citizens, and marching towards a holistic development. Thus, governance transcends the collective meaning of related concepts like the state, the government and the regime. It integrates a number of elements and principles of "good governance."

Good governance according to Downer (2000:27) is the process whereby public institutions conduct public affairs, manage public resources and guarantee the realization of human rights. Good governance accomplishes this in a manner essentially free of abuse and corruption, and with due regard for the rule of law. The true test of good governance is the degree to which it delivers on the promise of human rights, civil, cultural, economic, political and social rights. 'Good governance' was traditionally related to resource management (Rai, 2010:13).

For any government to rule effectively and in a citizen-friendly manner, it has to ensure good governance. Good governance should demonstrate the capacity to usher in decentralisation of powers that would prevent the sense of alienation among the elected representatives. A proper institution for redressal of grievances of citizens and transparency in administration are among the minimum measure that should be undertaken in the context of good governance. Thus, good governance is very important for economic efficiency and growth of a country (Srilatha, 2004:40). Healy and Robinson define good governance thus:

A high level of organisational effectiveness in relation to policy formulation and the policies actually pursued, especially in the conduct of economic policy and its contribution to growth, stability and popular welfare. Good governance also implies accountability, transparency, participation, openness and rule of law. It does not necessarily presuppose a value judgement, for example, a healthy respect for civil and political liberties, although good governance tends to be a prerequisite for political legitimacy.

Unescape (2008:3) stated that good governance has eight major characteristics. They are, participatory by both men and women which is the key to good governance. The next is the rule of law which requires fair legal frameworks that are enforced impartially. It also requires full protection of human rights, particularly those of minorities. Impartial 
enforcement of laws requires an independent judiciary and incorruptible police force. The third point is transparency which means that decisions taken and their enforcement are done in a manner that follows rules and regulations. The fourth is responsiveness which means that good governance requires that institutions and processes try to serve all stakeholders within a reasonable timeframe. The fifth characteristic is consensus orientation. Good governance requires mediation of the different interests in society to reach a broad consensus in society on what is in the best interest of the whole community and how this can be achieved. It also requires a broad and long-term perspective on what is needed for sustainable human development and how to achieve the goals of such development. The sixth characteristic is equity and inclusiveness. A society's well being depends on ensuring that all its member feel that they have a stake in it and do not feel excluded from the mainstream of society. This requires all groups, but particularly the most vulnerable have opportunities to improve or maintain their well being. The seventh characteristic is effectiveness and efficiency. Good governance means that processes and institutions produce results that meet the needs of society while making the best use of resources at their disposal. The concept of efficiency in the context of good governance also covers the sustainable use of natural resources and the protection of the environment. The last characteristic of good governance is accountability. It is a key requirement of good governance, not only governmental institutions but also the private sector and civil society organizations.

Governance can be good or bad; it is good when the governed can reap the positive benefits they expect from their government, but it is obviously bad when the opposite is the result. Towards the end of the 1980s, the international donor community together with the domestic opposition groups in a number of sub-Saharan African countries reached the conclusion that bad governance was the major cause of inefficient and ineffective delivery of public services and lack of development in the region (OdhiamboMbai, 2003:23). Conclusively, good governance is an ideal which is difficult to achieve in its totality. Very few countries and society have come close to achieving good governance in its totality. However, to ensure sustainable human development, actions must be taken to work towards this ideal with the aim of making it a reality.

\section{Public Service Delivery}

Service delivery is a comprehensive concept. In the context of governance, public service delivery is the result of the intentions, decision of government and government institutions, and the actions undertaken and decision made by people employed in government institutions (Rakate, 2006:18).

Service delivery has an impact on human development directly if it is delivered to people in the form of basic services such as education, health and water and sanitation which contribute to promoting human development. Service delivery also provides inputs into the growth process. Growth is a necessary condition for human development 
to be attained. In these two senses, access to adequate quantity and quality of services contributes to accelerating progress in economic growth and human development. However, service delivery requires resources for it to occur. The quantity and quality of these resources is a major determinant of the influence of these resources on growth and human development. These resources may be from internal or external sources. Effective service delivery will require scaling up of the quantity and quality of all resources, internal and external (Wangwe, 2010:7).

According to Nash and Nash (2004:15), effective service delivery is the provision of services to a buyer in such a way the buyer's expectations can be met or exceeded while at the same time the business remains viable. Effective service delivery therefore is rendering services that correspond to the customer's desires, needs and expectations. This concept emanates from the perceived need to treat members of the public that require government services like a private-sector entrepreneur would treat his/her customers. This is against the backdrop that a major obstacle to efficient and effective delivery of government services is the attitude of public servants to members of the public who are their customers (Fagbemi, 2006:47). Describing the requirements of the access principle for effective public service delivery, Batho (2006:11) explains that all citizens should have equal access to the services to which they are entitled. The openness and transparency principle has it that citizens should be told how national and provincial (states, local governments) departments are run, how much they cost, and who is in charge.

Public service delivery is commonly understood to mean the provision of public goods or social (education, health), economic (grants) or infrastructural (water, electricity) services to those who need (or demand) them.

\section{Research Methodology}

The data for this article were drawn mainly from secondary sources. In-depth literature studies were conducted to have a fundamental understanding of the issues raised in the article. It is a theoretical examination of accountability and good governance for effective service delivery in the public service in Nigeria through historical and descriptive research method and content analysis of the previous researches.

\section{Accountability and Good Governance: The Nexus}

In this postmodern era, commitment to the ideals of democracy, rule of law and a culture of accountability, rooted in constitutionalism, and defined in terms of good and responsible governance, has become a core value in measuring the performance of governments and regimes (Diamond, 1996:33). Even though the preponderance of literature on "good governance" links the concept to the language of development as coined by foreign aid donors, development agencies and international financial institutions since the 1990s, the concept is one that has deeper roots in accountability. 
Governments are powerful institutions run by the bureaucrats. Expanding government functions have brought in their trail bureaucratic expansion, and the bureaucracies have a constant impact on the quality of life of the citizens. There is, thus, an increasing concern today about how bureaucracies are using power (Bhattacharya, 2004:104). At the heart of these concerns is accountability; for what and to whom are bureaucracies answerable? How are the bureaucracies held accountable?

In discussing accountability, our major concern should be about how to ensure that those who wield power exercise it responsibly, so that they can be held accountable for their actions. The administrative agencies carry out the policies made by the people's representatives. They are indeed accountable to their political chiefs who in turn, are answerable to the legislature. In modern day administration, this policy-making and policy-implementation dichotomy does not hold good (Bhattacharya, 2004:108). The public demand in most democracies has been that there must be responsible use of power and authority and clearer means of administrative accountability.

Carrington, et al (2008:35) sees accountability and governance as flip sides of the same coin. Generally speaking they believe that holding a government institution accountable means first that the institution's policies and procedures are within the law of the land and reflect the best interests of the people, and second the institution operates in line with the particular and established governance arrangement.

Capturing the core essence of accountability and good governance, Kiyaga-Nsubuga (2006:131) posits that:

Good governance entails efficient and effective use of power and resources, constitutionalism and rule of law, justice and equity, electoral and participatory democracy, security of person and property, promotion of human rights, transparency and accountability (political, managerial and financial), exemplary and inspirational leadership, and popular participation in social and economic processes. Its facilitating conditions include a strong state, a robust and dynamic economy, a vibrant civil society, and informed and empowered citizenry.

Accountability is antithetical to monolog power. It establishes a dialogic relationship between accountable and accounting actors. It makes both parties speak and engage them both in public debate. It is therefore opposed not only to mute power but also to unilateral speechless controls of power (Shedlar, et al, 1999:29). Accountability expects compliance with due process of law and procedure with the public officers displaying the spirit that public power and resources are held on trust and that rendering of due account of stewardship is expected of them by the public from time to time. With such consciousness, it is expected, in an ideal system, that public power and resources are not to be used in a manner that forsake or seem detrimental to the publicly defined goals of the state. Instead, it should be seen 
as promoting the good of all. It is when this is done that good governance is attained (Omoregbe, 2006:45). However, systems that exhibit the pathologies of corruption can never be accountable and therefore good governance will certainly elude such system.

Good governance is itself an accountability-oriented concept applicable to specific target group. To follow the line of thinking of World Bank, good governance is synonymous with sound development management; it is an essential complement to sound economic policies. Governments are the main producers of public goods and they frame rules for the market to work efficiently. The institutional frameworks conducive to growth and poverty alleviation do not evolve on their own; rather, the emergence of such frameworks needs incentives and adequate institutional capacity to create and sustain them. It is in this context that the World Bank pinpoints accountability as an essential prerequisite of good governance (World bank, 1992:33).

The goal of governance extends beyond efficiency, effectiveness and economy to accountability, responsiveness, empowerment and participation. There is now an increasing pressure on political system, the administrative apparatus generated by civil society organisations, to share information and make decisions transparent. This is a step towards responsible governance. It can be made practically feasible, if the mindset of the politicians and bureaucrats undergo change, and they are receptive to the initiative of sharing information as well as power with the people (Bhattacharya, 2004:102).

From an alternative perspective, accountability plays a greater role in the process of public administration than indicated by the idea of answerability. In its simplest form, answerability implies that accountability involves limited, direct and most formalistic responses to demands generated by specific institutions or groups in the public agency's task environment. More broadly conceived, public administration accountability involves the means by which public agencies and their workers manage the diverse expectations generated within and outside the organization.

Accountability foster good, ethical governance and are fundamentally needful for building public trust in leadership. Abused and neglected over time, the Nigerian public has gradually grown accustomed to not trusting its leadership any longer. People have become virtually disconnected from the government, not only in the political sense, but particularly in the civic, moral and ethical sense of duty. They have stopped to expect anything good from their government and have lost the sense of attachment and obligation to duty and society. As argued by Abata and Adejuwon (2012:25), without a reawakening of the culture of accountability and transparency lost over the years, the trusting relationship needed to forge between the government and the governed for the actualization of good governance will not materialize.

The evidence of accountability and governance paralysis are not hard to find in contemporary Nigerian society. A few of them are cited below. They range from documented real-life experiences to survey-based researched data. Perhaps the most tragic evidence is the near-complete breakdown of law and order. Nigeria has gradually degenerated into a society without a discernible legalistic framework for law 
enforcement or visible platform for moral/judicial redress. In contemporary Nigerian society, anyone favoured in political patronage can literally do almost anything and get away with it. Some of the more common crimes routinely staged by the politicallyconnected mavericks include money-laundering schemes, uncontrollable theft of public money, assassin killing of political opponents, wilful manipulation of electoral votes, forceful extortions, and other self-gratification conspiracies (Omotoye, 2011:168).

In Nigeria, the diagnostic survey conducted in 2001 into the Federal Government public procurement revealed that "Nigeria lost several hundred billions of Naira over the last few decades due of flagrant abuse of procedures, lack of transparency and merit in the award of contracts in the public sector and accountability quandary (Okpala, 2012:126). The problem of this research article is based on the perceived weak accountability of government fund by public servants in Nigeria which has not only increased the height of corruption but also resulted in enormous waste of national resources and decay of economic infrastructure within the economy.

The state of accountability in Nigeria has been observed to be weak by the World Bank. In its report on the Observance of Standards and Codes (ROSC) on Nigeria issued in 2004, the World Bank observes that accountability and governance in Nigeria suffer from institutional weaknesses in regulation, compliance and enforcement of standards and rules. As a result, public service delivery in Nigeria is bedevilled with governance crisis. It is apt to point out that accountability and participation are necessary conditions for improved delivery of public services and for good governance.

Without good governance, there can be no accountability. Good governance plays a critical role in ensuring collaborative, peaceful, coexistence and progressive process of democratic culture and socialization. It also attracts investment to a country, improving productivity and competitiveness, promoting political stability and enhances rapid socio-economic development. There is therefore, a critical link between accountability and good governance.

\section{Public Accountability, Good Governance and Effective Public Service Delivery: The Nigerian Dilemma}

Accountability is one of the buzz words in service delivery. As noted by Abata and Adejuwon, (2012:30), it is a sine qua non for effective service delivery in the public sector. This enables a government to be responsive to the governed. For too long, and historically speaking, that is, if one takes a long view from the colonial era, and also as a result of the long spell of military intervention in the country's polity, these virtues of modern government the world over have remained a fairy tale and a mirage for the Nigerian people. Accountability constitutes pivotal features of any respectable public official or professional practitioner. An effective government rest majorly on the available human and material resources which the nation could mobilize and harness for government. Without mincing words, the issue of accountability in Nigeria has become 
a subject of global concern and worry as it underpins the very essence of human development at every level of human relationship. The main idea is that service providers should have better incentives to respond to the needs of beneficiaries. Accountability applies in the political, bureaucratic as well as market spheres (Besley \& Ghatak, 2007:129).

Accountability is a fundamental but under-developed concept in Nigerian public administration. Scholars and practitioners freely use the term to refer to answerability for one's actions or behaviour. Administrators and agencies are accountable to the extent that they are required to answer for their actions. Beyond this on basic notion of answerability, there has been little refinement of the term. Most of the discussions on the literature centre on the "best" strategy for achieving accountability.

Accountability in service delivery may be conceived of as processes through which communities and households can hold providers responsible for the adequacy and effectiveness of the services they offer. For poor and marginalized communities and households, public accountability can be achieved through giving them both voice and suffrage; for policymakers, accountability can be demanded through the social compact in which governments assist, finance and regulate providers of health care, nutrition and environmental health services.

In Nigeria, the level of accountability among public officials in the management of public affairs has consistently declined since independence. The rate of annual economic growth of the country has generally declined over the period. At the same time, the efficient and effective delivery of public service to the ordinary citizen has continuously deteriorated. A combination of these two factors has resulted in widespread unemployment and poverty in the country.

A recurring decimal in the exposition of Nigeria's development dilemma is the recognition of corruption as the most imposing albatross. Almost all facets of the Nigerian economy are haunted by the spectre of corruption. Corruption is the single most potent impediment to Nigeria's development. There is discernible trajectory in the mutation of corruption. The intensity of corruption in Nigeria is proportionally correlated to the epochal transmutation of its productive forces: from a bouquet of cash crops to oil economy. The fact that the new democratic leadership had to rely on political power as the means of creating their economic base is a fact of immense significance. It unfortunately created a tendency to make political power the means of accumulation (Ake, 1981:3). It was this use of political power to create wealth by the ruling class in the period following independence that spawned corruption.

Revelations at the recent probes into the Power Sector, Energy sector (NNPC) are indications of the rottenness in our governance and if such efforts are extended to other sectors such as agriculture, similar revelations will no doubt be the result. For example, in the Punch newspaper of Sunday, 4th May 2008, a top official of the Federal Ministry of Agriculture claimed that Nigeria lost 22.2 billion naira in Fertilizer scam between 2001 and 2007 (Adenuga, 2013:779). 
Since independence, Nigeria has formulated various legal instruments and established a number of watchdog institutions (like EFCC, ICPC, Code of Conduct Bureau) for regulating and monitoring the ethical behaviour of its public officials. Besides, in the early 1990s, domestic opposition groups assisted by the international community demanded and eventually achieved the restoration of competitive party politics or multi-partysm in the country. However, despite the existence of a number of legal instruments and watchdogs institutions for regulating and monitoring the ethical standards of public officials, and the adoption of multipartysm, the management of public affairs and institutions by those who are entrusted with positions of authority in the country has not improved.

Some of the high profile cases of corruption in Nigeria (Abdulrahman, 2013:9; Mez, 2010:7) include those that involved:

- Ayo Fayose, former Governor of Ekiti State - N1.2billion

- Aminu Turaki - N36billion

- Chief Bode George - N100billion

- Rasheed Ladoja, former Governor of Oyo State - N6billion;

- Adamu Abdullahi, former Governor of Nasarawa State - N15billion

- Senator Nicholas Ugbade N5.2billion

- Attahiru Bafarawa, former Governor of Sokoto State, N15billion, etc.

- Other former Governors charged for various financial crimes are Edo States' Lucky Igbinedion, Rivers Peter Odili and Chimaroke Nnamani of Enugu state. ExGovernor Nnamani and two of his former Commissioners, Peter Mba and Spine Ejiofor were alleged of stealing N5.6 billion while some companies were also linked to him (Ademola, 2011:309).

Apart from the above, the former President's daughter, lyabo Obasanjo-Bello, a senator of the Federal Republic was involved in two separate scandals. In December, 2007, lyabo Obasanjo Bello was involved in a contract scandal amounting to N3.5 billion involving her and an Australian firm. Senator lyabo Obasanjo was again involved in another financial scandal of mismanagement of funds in the Ministry of Health. It was this scandal that led to the resignation of Mrs. Adenike Grainge and her Deputy, Architect Gabriel Aduku. lyabo Obasanjo was later arraigned in court for over N300 million unspent budget scam (Muhammed, 2013:127).

Mallam Nuhu Ribadu, the former EFCC Chairman maintains that the over $\$ 400$ billion that had been looted from the Commonwealth by the leaders is "six times the total value of resources committed to rebuilding Western Europe after the Second World War (Ademola, 2011:312). The 2008 Corruption Perception Index (CPI) released by the Transparency International revealed that the country was rated 121 out of 180 countries surveyed. On the scale of 10.0, Nigeria scored 1.6 in 1999; 1.2 in 2000; 1.0 in 2001; 1.6 in 2002; 1.4 in 2003; 1.6 in 2004; 1.9 in 2005; 2.2 in 2006; 2.2 in 2007; and 2.7 in 2008 (TI, 2008:11). This of course became a source of embarrassment to Nigerian officials 
travelling abroad and Nigerian nationals all over the world. As a result of wanton corruption, the international community became so much concerned with the lack of good governance in the country. Consequently, the Obasanjo administration was placed under international pressure and threats of sanctions to implement measures against corruption and other forms of financial offences (Mohammed, 2013:125).

As noted by Odhiambo-Mbai (2003:2), the continued deterioration of the level of accountability among public officials in the country shows that the adoption of multipartysm has not contributed to good governance. Given these facts, these pertinent questions therefore arise: what have been the major causes of the lack of, or poor accountability among public official in Nigeria? Why have the existing instruments and watchdog institutions for regulating and monitoring ethical standards of public officials failed to ensure accountability? What strategies need to be adopted in order to enhance accountability in governance among public officials?

It is quite clear that since independence, the level of public accountability in Nigeria has consistently deteriorated. Thus, from the early 1990s, in order to improve the efficient and effective public services delivery and promote economic development, domestic opposition groups, supported by the international community in Nigeria began to demand good governance. Needless to say, the continued deterioration of accountability in governance led to the decline in the standard of provision of public services and economic growth. These in turn resulted in increased unemployment and general poverty in the country. However, in the case of Nigeria the deterioration of public service accountability may be attributed to the following factors:-

- The autocratic or patron-client relations political process;

- The involvement of public servants in private business

- Poor terms and conditions of service

- Deterioration of professionalism in the public service

- Ethnicity and nepotism.

Wends (2004:7) has identified the causes of poor service delivery in Nigeria as inadequate resources, management and misappropriation of funds, inadequate motivation of staff, lack of technical competence, use of obsolete and outdated technology, undue government interference and corruption. Akhakpe (2008:54) suggests additional factors as nepotism, bureau-pathologies, poor infrastructural facilities, tribalism, favouritism, federal character principle, the poor attitude of staff to government work, and bad human resources management. The most embarrassing of these is corruption.

Due to widespread corruption, abuse of office and the general deterioration of other ethical standards in the country, one is likely to assume that there is no control mechanism that could be used to enforce accountability. Yet this is not the case. Nigeria has many legal and quasi-legal instruments and other watchdog institution specifically formulated and designed for controlling public service ethics. Despite this fact, public accountability constantly deteriorates as we have seen. 
Generally, it is acknowledged that virtually all the unethical practices such as bribery and corruption, patronage, reposition, embezzlement, influence peddling, the use of one's position for self-enrichment, bestowing of favours on relatives and friends, moonlighting, late coming to work, abuse of public property, and the leakage and/or misuse of government information that constitute the lack of accountability in governance which currently characterise the country's public service (Odhiambo-Mbai, 2003:5). Furthermore, during the last five years, the respected and authoritative Transparency International has consistently placed Nigeria among the top ten most corrupt countries in the world.

The failure of Nigeria to restore the high level of accountability similar to the one it boasted of immediately after independence despite the restoration of multipartysm more than a decade ago, shows that either the kind of multipartysm adopted has failed to democratise the country, or that democratisation is not a sine-qua non for accountability in governance. It is quite apparent that the former is the case.

In spite the institutional framework put in place by successive governments to checkmate corruption, it only thrived luxuriantly. Several factors appeared to have undermined these frameworks namely, lack of political will; active connivance of those in authority, and unaccountable nature of governance in the political history of Nigeria (Nwosor, 2011:2).

\section{Towards the Enhancement of Accountability and Good Governance in Service Delivery in Nigeria}

Arising from the above analysis, it may be in order to make certain suggestions on how public accountability in Nigeria could be enhanced. From the above discussions, it is obvious that Nigerians need a change of attitude to governance if the nation must develop and move forward.

The challenges of public service delivery in Nigeria are surmountable, but to overcome them and lay the foundation for a lasting development, the federal government should maintain peace and stability, which is precondition for rebuilding confidence and providing security to the society and investors, both national and foreign. For a meaningful, impact-felt public service delivery to be successfully carried out in Nigeria, it must put into consideration the behavioural pattern, the social context, as well as cultural milieu of the people whom the service is meant for, together with the vehicle of the delivery of services. This means that there is need to exploit indigenous knowledge in carrying out any required services in the public sector (Adejuwon, 2012:89).

Nigeria is not short of legislations to enthrone public accountability, yet it is unable to do so. Several factors are at play in making the task of eradicating corruption and enthroning public accountability in its body-politic a herculean task: these factors include lack of political will on the part of the government, slow judicial process, 
politicisation of the anticorruption crusade, elite conspiracy, playing the ethnic card and indifference of the masses (Nwosor, 2011:19). Firstly, the political and administrative machineries which brings people to power in Nigeria must be totally overhauled in order to produce dedicated, enlightened and God fearing individuals who will be at the helm of affairs in the country. Conscious efforts at improving public service delivery in Nigeria are still in its infancy. A lot of commitment and political will from public office holders are required to change the value orientation of Nigerians, from that of the "Nigerian Factor" to operating an efficient, effective economical and accountable public service (Fagbemi, 2006:104). Promoting accountability therefore requires identifying who is to be held accountable for what, to whom and how. In other words, it is an essential, in thinking about accountability in a given situation, to distinguish between agents, individuals or organizations that make decisions, and their principals, who have authorized their actions (Keohane, 2002:5).

Strengthening accountability must be tailored to different modes of service delivery. At the primary level of community and family services; including such factors as information and social support for promoting breastfeeding or newborn care services; the ability of households to purchase commodities, access information on services and transform both into better health outcomes is central to increasing demand-side accountability. Citizens are increasingly asking for workable solutions to everyday problems spurred by the unresolved challenges of poverty, hunger, pandemics, environmental degradation, energy bottlenecks and security threats, only to name a few.

Effective service delivery must be tailored to the circumstances of Nigeria. This requires a good evidence base and sound economic reasoning. The best way to make effective policy is to make sure that policy is evidence based and learnt from experience elsewhere as well as working to expand the evidence base for Nigeria. Equally, it is important to connect this to our wider understanding of the principles of good policymaking in this area.

In order to bring sanity back to Nigerian public service, all the unprofessional tendencies such as ethnicity and nepotism in appointments and promotions, lack of security of tenure and appointment of non-career public servants into key positions in the public service should be stopped. This would discourage public servants who are tempted to abuse their public offices due to frustrations not to do so. In addition, Joseph (1990:7) also recommends that:

...the most decisive way in which (political) accountability can be achieved is through the requirement that a government's continuation in office depends on the active approval of the people as expressed in competitive election.

He is of the opinion therefore that effective (good) governance requires institutional pluralism, communal empowerment and meaningful popular participation.

Zabra (2010:6) emphasizing the role of public scrutiny and ethical standard in institutionalizing the culture of accountability at public offices reaffirms that, public 
scrutiny is a very important instrument for sustaining accountability and trust in public life and public officers, especially the elected officials, should be subjected to higher scrutiny except with regard to personal life and standard; and ethical standard as an effective way of sustaining democracy. In this regard, the watchdog institutions such as Parliament, the Judiciary and Police should be strengthened to undertake their roles effectively. Although there are a number of watchdog institutions in the country for controlling public accountability, as we have seen none of these are independent and effective enough to undertake the task. These institutions should be well staffed with competent personnel and they should be provided sufficient resources to enable them perform their functions efficiently and effectively. The anti-corruption campaigns and other related campaigns to entrench transparency and accountability must be vigorous not timid. Such campaigns must be consistent in applications and must be devoid of selectivity in applications and choice of battle fronts if they are to retain credibility and to be internalized by all Nigerians (Idachaba, 2006:90).

In addition, extending incentive rewards to good workers is also another effective way of promoting public accountability in the public service. Ultimately, public accountability in Nigeria will most likely be achieved through vigorous democratisation of the state. Thus, we propose that the ongoing democratisation process in Nigeria should be invigorated. Lastly, what constitute good governance has been extensively discussed in this article as can be seen above. Let Nigerian leaders follow these points religiously and at the long last, there will be light at the end of the tunnel for the entire Nigerian nation.

\section{Conclusion}

This work has been able to examine the concept of accountability and good governance, which is very essential as a precondition for effective service delivery. The widespread lack of public accountability in governance in Nigeria certainly undermines the provisions of public services and economic development. Nigeria is showing elements of weak governments, institutional and high profile ethical feature as well as increasing inability of governments to deliver on key deliverables such as poverty eradication, employment generation, economic development, security and general improvement in the lives of the people. Politicians and public servant must demonstrate high ethical standards by being transparent, accountable and trustworthy, consistent in character, courageous and dedicated and committed to duty (Adeyemi, et al, 2012:17). It is only through a vigorous democratisation process that public accountability in governance can be restored in the country. Thus, the burden is upon Nigerians to constantly demand accountability from their governments.

Accountability is no doubt one of the cornerstones and core elements of good governance because public participation/inclusion is a catalyst for accountability. It is so because it is a means for the participating public or communities to hold public 
authorities accountable for service delivery. It is then logical to deduce that accountability is an offshoot of social/citizen inclusion in governance. The two are simply reinforcing. It is therefore imperative for us to dwell on the subject of "accountability" in addition to social inclusion in this work (Adesopo, 2011:5). The ways of ensuring accountability and good governance in Nigeria as enumerated in this article will help to create avenue for effective service delivery. And finally, the work made some recommendations which if adopted will help to ensure accountability and good governance in Nigeria for the purpose of effective service delivery to the citizens.

\section{List of References}

- Abata, M.A and Adejuwon, K.D. 2012. Accountability and Transparency in Public Financial Management in Nigeria: Challenges and Prospects. International Journal of Marketing and Technology. 2(5): 14-33

- Abdulrahman, S. 2013. The Ramification of Bribery and Corruption on Growth and Development of Corporate Governance in Nigeria. Proceedings of 6th International Business and Social Sciences Research Conference 3 - 4 January.

- Ackerman, J.M. 2005. Social Accountability in the Public Sector: A Conceptual Discussion. Social Development Papers: Participation and Civic Engagement. No. 82: March.

- Adejuwon, K.D. 2012. Public Sector Reform and Service Delivery in Africa: The Nigerian Perspective. Germany: Lambert Academic Publishing.

- Ademola, A. 2011. Endangering Good Governance for Sustainable Democracy: The Continuity Struggle against Corruption in Nigeria. Journal of Research in Peace, Gender and Development. 1(11):307-314 December

- Adenuga, A.A. 2013. Good Governance and Accountability in Nigeria's Developmental Dilemma. Mediterranean Journal of Social Sciences. 4(2):777-782

- Adeyemi O.O; Akindele, S.T; Aluko, O.A. and Agesin, B. 2012. Institutionalizing the culture of accountability in local government administration in Nigeria. African Journal of Political Science and International Relations 6(4):81-91, April

- Agbaje, E.B.A 2004. Corruption, Accountability and Good Governance: Reflections on Governance in Nigeria's Fourth Republic, 1999-2003. International Review of Politics and Development. 2(2):79-99

- Ake, C. 1981. A Political Economy of Africa. Harlow: Longman Group Limited. 
- Akhakpe, I. 2008. Administration and Management of Public Enterprises in Nigeria. Lagos: Pumark Nigeria Limited

- Bardhan, P. 2002. Decentralization of Governance and Development. Journal of Economic Perspectives, 16(4): 185-205

- Besley, T and Ghatak, M. 2007. Reforming Public Service Delivery. Journal of African Economies, 16(1): 127-156

- Bhattacharya, M. 2004. Nexus between Accountability and Good Governance: Conceptual and Practical Issues. Sahni, P and Medury, U (eds). Governance for Development: Issues and Strategies. New Delhi: Prentice-Hall of India Private Limited

- Blind, P.K. 2011. Accountability in Public Service Delivery: A Multidisciplinary Review of the Concept. Paper Prepared for the Expert Group Meeting Engaging Citizens to Enhance Public Sector Accountability and Prevent Corruption in the Delivery of Public Services, Vienna, Austria 7-8 and 11-13 July 2011.

- Carrington, W; DeBuse, J and Heejin, L. 2008. The Theory of Governance and Accountability" (Retrieved from www.uiowa.edu/ifdebook/issues/accountability/Governance_\&_Accountability -Theorypdf

- Diamond, L. 1996. Is the Third Wave Over?, Journal of Democracy, 7(3):20-37

- Dower, A. 2000. Good Governance: Guiding Principle for Implementation. Australia: Ministry for Foreign Affairs.

- Fagbemi, A. 2006. Customer Service Delivery in Public Management. Lagos: Concept Publication Ltd

- Fosu, A.K. and T. C. I. Ryan. 2004. Public Sector Delivery: A Synthesis. Journal of African Economies, 13(1): 137-141

- Hondeghem, A. 1998. Ethics and Accountability in a Context of Governance and New Public Management. Amsterdam: IOS Press.

- Honest, P.N. 2006. Public-Private Partnership (PPP) in Service Delivery: Application, Reasons, Procedures, Results and Challenges in Tanzanian Local Government Authorities (LGAs). A paper presented at 28th AAPAM Annual Roundtable Conference, Arusha, Tanzania 4th - 8th December 2006

- Idachaba, F.S. 2006. Culture, Transparency and Accountability in Nigeria", in Attitude matters, The Role of Attitudes in Nigeria's Development. Proceedings of a national seminar organized by the National Orientation Agency (NOA) and the Nigerian Television Authority (NTA). Ibadan: Spectrum Book Limited. 
- Joseph, R. 1990. Political Renewal in Sub-Saharan Africa: The Challenge of the 1990s. In Carter Centre. African Governance in the 1990s. Atlanta: Carter Center.

- Joshi, D. 2011. Public Service Accountability: A Comparative Perspective. Hartford, $\mathrm{CT}$ : Kumarian Press,

- Keohane, R.O. 2002. Political Accountability. A paper prepared for Conference on Delegation to International Organizations, Park City, Utah, May 3-4, 2002

- Kiyaga-Nsubuga, J. 2006. Commonwealth Secretariat, Local Democracy, Good Governance and Delivery of MDGs in Africa. Background Paper. 57(61).

- Krikpatrick, E.M. 1980. Chambers Universal Learners Dictionary. Ibadan: Chambers and Spectrum Books Ltd

- Mez, J.A. 2010. Corruption in Nigeria: A Challenge of Nigeria Diasporas: A Ypoium on Nigeria at 50: Leon and Opportunities in Commemoration of Nigeria' 50th Independence Anniversary. Sacramento State University on October 1, 2010. Sponsored by Sacramento Association of Nigerians \& California State University at Sacramento Center for African Peace \& Conflict Resolution (CAPCR)

- Mitel, I. 2007. Simplifying and Transforming Service Delivery in Government Citizen Interaction Centres. White Paper, October

- Muhammed, S. 2013. Corruption in Nigeria: A Challenge to Sustainable Development in the Fourth Republic. European Scientific Journal. 9(4): 118-137

- Nash, S and Nash, D 2003. Delivering Outstanding Customer Service. New Delhi: USB Publishers Distributors Ltd

- Nwosor, A. 2011. Bureaucratic and Systemic Impediments to Public Accountability in Nigeria. International Journal of Politics and Good Governance. 2(24):1-20

- Odhiambo-Mbai, C. 2003. Public Service Accountability and Governance in Kenya since Independence. African Journal of Political Science. 1(8):113-146

- Okpala, K.E. 2012. Fiscal Accountability Dilemma in Nigeria Public Sector: A Warning Model for Economic Retrogression. Research Journal of Finance and Accounting. 3(6):113-131

- Ola, R.O.F and Effiong, O.J. 1999. Public Financial Management in Nigeria, Lagos: Amfitop Books.

- Olarinmoye, O. 2011. Accountability in Faith-Based Development Organizations in Nigeria: Preliminary Explorations. Oxford: Global Economic Governance Programme, University of Oxford

- Omotoye, R.O. 2011. Restoring Financial Transparency and Accountability in Nigeria. International Research Journal of Finance and Economics. 78:158-170 
- Polidano, C. and Hulme, D. 1997. No Magic Wands: Accountability and Governance in Developing Countries. Regional Development Dialogue 18(2)

- Rai, S. 2010. Transparency and Accountability in Governance and Right to Information in India. Jaipur: Department of Political Science, University of Rajasthan

- Rakate, N.F. 2006. Transformation of the South African Public Service. Pretoria: Research Report. University of Pretoria, South Africa.

- Sahni, P. 2004. Introduction. Sahni, P and Medury, U (eds). Governance for Development: Issues and Strategies. New Delhi: Prentice-Hall of India Private Limited

- Shedler, A; Diamond, L and Plattner, M.F. 1999. The Self-Restructuring State: Power and Accountability in New Democracies. Colorado: Lynne Reinner Publishers

- Srilatha, P. 2004. Governance in India: The Issue of Corruption. Sahni, P and Medury, U (eds). Governance for Development: Issues and Strategies. New Delhi: Prentice-Hall of India Private Limited

- Unescape, 2008. Poverty and Development Division Good Governace, UN Web Site Locator

- Wangwe, S. 2010. Foreign Aid, Accountability and Service Delivery in Africa. Dar es Salaam: Daima Associates Limited

- Wendy, T. 2004. Delivering Service in Nigeria: A Roadmap. London: Office of Public Service Reform

- World Bank. 1992. Governance and Development. Washington, D.C: World Bank

- World Development Report, 2004. Making Services Work for Poor People. Washington, DC: The World Bank,

- Zabra, E. 2010. Good Governance, Accountability and Trust. Summary of Proceedings on CAPAM African Regional Conference, Abuja, Nigeria, May 17-19

\section{AUTHOR'S CONTACT:}

ADEJUWON, Kehinde David

Department of Public Administration

Faculty of Management Sciences

Lagos State University, Ojo

Lagos, Nigeria

Email: adekennytee@gmail.com 